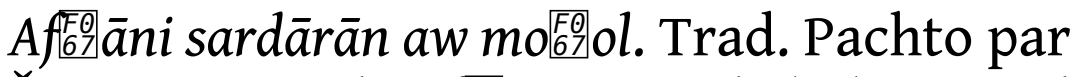 Š. M. Karimi. də Af Peshawar, 2001, $10+251$ p. [Les princes afghans et les moghols]
}

\section{Nadjib Manalaï}

\section{(2) OpenEdition}

\section{Journals}

Édition électronique

URL : http://journals.openedition.org/abstractairanica/34438

DOI : $10.4000 /$ abstractairanica.34438

ISSN : 1961-960X

Éditeur :

CNRS (UMR 7528 Mondes iraniens et indiens), Éditions de l'IFRI

Édition imprimée

Date de publication : 15 mai 2003

ISSN : 0240-8910

\section{Référence électronique}

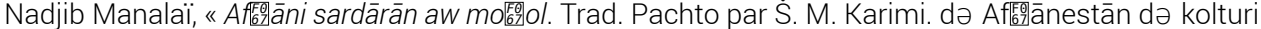
wade toləna. Peshawar, 2001, $10+251$ p. [Les princes afghans et les moghols] », Abstracta Iranica [En ligne], Volume 24 | 2003, document 129, mis en ligne le 05 janvier 2010, consulté le 25 septembre 2020. URL : http://journals.openedition.org/abstractairanica/34438; DOI : https://doi.org/10.4000/ abstractairanica.34438

Ce document a été généré automatiquement le 25 septembre 2020.

Tous droits réservés 


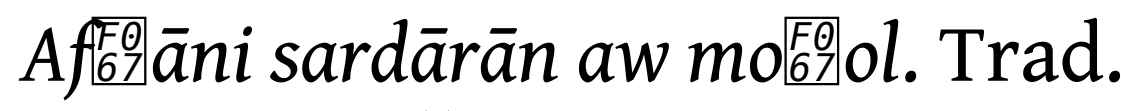 Pachto par Š. M. Karimi. də Af[E] ānestān də kolturi wade tolona. Peshawar, 2001, $10+251$ p. [Les princes afghans et les moghols]
}

\author{
Nadjib Manalaï
}

1 R. Joshi, professeur à l'université d'Allahabad en Inde, analyse dans son ouvrage le rôle des princes et chefs militaires pachtounes qui ont gravité autour de la cour des Moghols en Inde entre 1526 et 1707. Les chefs pachtounes, héritiers en quelque sorte des dynasties afghanes qui ont régné sur l'Inde avant l'avènement des Moghols, ont entretenu avec ces derniers des relations extrêmement ambiguës : d'une part ils furent instrumentalisés pour l'équilibre des pouvoirs entre les chefs moghols, rajput et farsis et d'autre part, ils faisaient l'objet d'une méfiance constante tant en raison du passé historique que des troubles permanents qui agitaient leur pays d'origine.

2 Une annexe d'une cinquantaine de pages donne la liste des fonctions et des fiefs détenus par des chefs pachtounes sous l'empire des Grands Moghols de l'Inde.

\section{INDEX}

Thèmes : 4.2.3. Inde musulmane 
AUTEURS

NADJIB MANALAİ

INaLCO - Paris 